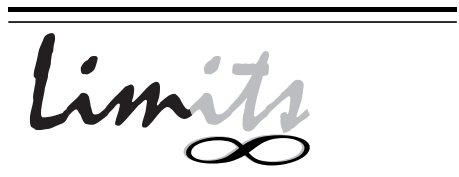

J. Math. and Its Appl.

ISSN : $1829-605 \mathrm{X}$

Vol. 6, No. 1, May 2009, 11-24

\title{
PENGAMBILAN KEPUTUSAN DENGAN MENGGUNAKAN METODE MAXIMUM SCORE OF THE TOTAL SUM OF JOINT PROBABILITIES
} (MSJP)

\author{
F. Agustini W. ${ }^{1}$, A. D. W. Sumari ${ }^{2}$,R. Sita Safitri ${ }^{3}$ \\ ${ }^{1}$ Jurusan Matematika, FMIPA ITS Surabaya \\ ${ }^{2}$ Department of Electronics Indonesian Air Force Academy Yogyakarta \\ ${ }^{1}$ farida_sahlan@yahoo.com, ${ }^{2}$ arwin.sumari@gmail.com, ${ }^{3}$ tasya_c9@yahoo.com
}

\begin{abstract}
Abstrak
Pengambilan keputusan merupakan hal yang sangat penting bagi manusia untuk mengestimasi langkah apa yang harus diambil saat ini atau di masa yang akan datang. Metode yang banyak diaplikasikan dalam pengambilan keputusan adalah metode inferensi Bayesian dipadukan dengan teknik Maximum A Posteriori (MAP). Kombinasi metode teknik ini memiliki keterbatasan ketika dihadapkan pada permasalahan-permasalahan yang bersifat multi-hipotesa multiindikasi, sehingga digunakan metode Maximum Score of the Total Sum of Joint Probabilities (MSJP) dalam pengambilan keputusan. Salah satu studi kasus yang mendukung dalam pengaplikasian metode MSJP yaitu mengenai ekspresi interaksi gen-gen dari waktu ke waktu. Dalam penelitian ini menggunakan data yeast cell cycle sebagai studi kasus mengenai fenomena ekspresi gen. Data gen yeast yang diteliti adalah yeast tipe elu dengan 25 gen dan 36 gen dalam 18 deretan waktu.

Katakunci: Pengambilan keputusan, Bayesian, MSJP, yeast cell cycle
\end{abstract}




\section{Pendahuluan}

Manusia adalah makhluk yang kompleks dan penuh pertimbangan dalam menentukan satu pilihan ketika dihadapkan pada fakta-fakta atau indikasiindikasi yang ditemui di sekitar lingkungannya. Oleh karena itu, manusia melakukan inferensi (penarikan kesimpulan) dari informasi yang diperoleh panca inderanya sebagai dasar pengambilan keputusan terhadap peristiwa yang sedang diamati. Metode yang telah banyak diaplikasikan dalam pengambilan keputusan adalah metode inferensi Bayes dipadukan dengan teknik Maximum A Posteriori (MAP). Kombinasi metode teknik ini memiliki keterbatasan ketika dihadapkan pada permasalahan-permasalahan yang bersifat multi-hipotesa multi-indikasi yang sering dihadapi manusia dalam kehidupan nyata. Untuk meminimalkan keterbatasan tersebut, pada penelitian ini digunakan metode Maximum Score of the Total Sum of Joint Probabilities (MSJP) dalam pengambilan keputusan. Metode MSJP merupakan pengembangan dari metode Bayes yang dikembangkan oleh [7].

Salah satu studi kasus yang mendukung dalam pengaplikasian metode MSJP yaitu mengenai ekspresi interaksi gen-gen dari waktu ke waktu. Pada penelitian ini menggunakan data yeast cell cycle sebagai studi kasus mengenai fenomena ekspresi gen. Dari penelitian Zubir (2008), terdapat database yeast dengan 25 gen (yeast 25 sequence) dan 36 gen (yeast36 sequence).

Masing-masing terdiri dari beberapa tipe seperti : alpha, cdc15, cdc28, cho, elu dan tf [1]. Data gen yeast yang diteliti adalah yeast25 dan yeast36 tipe elu. Dengan menggunakan metode MSJP, akan diprediksi ekspresi gen di waktu mendatang dan akan dicari gen yang menghasilkan ekspresi tertinggi sehingga mempermudah peneliti dalam memeriksa interaksi gen selanjutnya untuk mendapatkan ekspresi gen yang lebih baik.

\section{Metode Inferensi Bayesian}

Anggap terdapat dua peristiwa $A$ dan $B$. Probabilitas $A$ sama dengan

$$
P(A)=P(A \cap B)+P(A \cap \bar{B})
$$

Himpunan $B$ dan $\overline{(B)}$ merupakan himpunan peristiwa-peristiwa yang bersifat saling terpisah (mutually exclusive). Hukum probabilitas total 
dapat diperluas di mana ruang sampel $S$ disekat dalam partisi-partisi $B_{1}, B_{2}, B_{3}, \ldots, B_{m}$ sehingga probabilitas total diperoleh sebagai berikut :

Atau menjadi persamaan (1).

$$
\begin{aligned}
& P(A)=\sum_{j=1}^{m} P\left(A \cap B_{j}\right) \\
& \text { (1). }
\end{aligned}
$$

$$
\begin{aligned}
P(A) & =P\left(A \mid B_{1}\right) P\left(B_{1}\right)+P\left(A \mid B_{2}\right) P\left(B_{2}\right)+\cdots+P\left(A \mid B_{m}\right) P\left(B_{m}\right) \\
& =\sum_{j=1}^{m} P\left(A \mid B_{j}\right) P\left(B_{j}\right)
\end{aligned}
$$

Proses inferensi bayes adalah sebagai berikut, jika mempunyai beberapa hipotesa $A_{1}, A_{2}, \ldots, A_{n}$ yang mutually exclusive dan exhaustive, kemudian ada beberapa fakta $B_{1}, B_{2}, \ldots, B_{m}$, maka probabilitas bersyarat a posteriori untuk tiap objek $A_{i}$ ditunjukkan oleh persamaan (1) [6].

$$
\begin{aligned}
& P\left(A_{i} \mid B_{1}, B_{2}, \ldots, B_{m}\right)=P\left(A_{i} \mid B_{j}\right)=\frac{P\left(B_{j} \mid A_{i}\right) P\left(A_{i}\right)}{P\left(B_{j}\right)} \\
& =\frac{P\left(B_{j} \mid A_{i}\right) P\left(A_{i}\right)}{\sum_{i=1}^{n} P\left(B_{j} \mid A_{i}\right) P\left(A_{i}\right)} \\
& =\frac{P\left(B_{j} \mid A_{i}\right) P\left(A_{i}\right)}{P\left(B_{j} \mid A_{1}\right) P\left(A_{1}\right)+\cdots+P\left(B_{j} \mid A_{n}\right) P\left(A_{n}\right)}
\end{aligned}
$$

\begin{tabular}{|c|c|c|c|c|}
\hline$A_{i}$ & \multicolumn{4}{|c|}{ Hipotesa $A_{i}$} \\
\hline$B_{j}$ & & 1 & $\ldots$ & $N$ \\
\hline \multirow{6}{*}{$\begin{array}{l}\text { Indikasi } \\
\mathrm{Bj}\end{array}$} & 1 & $P\left(A_{1} \mid B_{1}\right)$ & $\cdots$ & $P\left(A_{n} \mid B_{1}\right)$ \\
\hline & 2 & $P\left(A_{1} \mid B_{2}\right)$ & $\ldots$ & $P\left(A_{n} \mid B_{2}\right)$ \\
\hline & $\ldots$ & $\ldots$ & $\ldots$ & $\ldots$ \\
\hline & $\mathrm{j}$ & $P\left(A_{1} \mid B_{j}\right)$ & $\ldots$ & $P\left(A_{n} \mid B_{j}\right)$ \\
\hline & $\ldots$ & $\ldots$ & $\ldots$ & $\ldots$ \\
\hline & $\mathrm{m}$ & $P\left(A_{1} \mid B_{m}\right)$ & $\ldots$ & $P\left(A_{n} \mid B_{m}\right)$ \\
\hline
\end{tabular}

dengan $i=1,2, \ldots, n$ merupakan jumlah dari hipotesa-hipotesa $A$ dan $j=1,2, \ldots, m$ adalah jumlah dari indikasi-indikasi $B$.

Tabel 2.1 Ilustrasi Metode Inferensi Bayes dengan teknik MAP 
Metode Inferensi Maksimum Score of the Total Sum of Joint Probabilities (MSJP) Metode inferensi Maximum Score of the Total Sum of Joint Probabilities (MSJP) merupakan perbaikan dari metode inferensi bayesian dengan teknik MAP. Metode MSJP ditunjukkan pada persamaan (3).

$$
\begin{aligned}
& P\left(A_{i} \mid B_{1} \& \ldots \& B_{m}\right)_{\text {estimated }} \\
& =\max _{i \in I}\left\{\frac{\sum_{j=1}^{m} P\left(A_{i} \mid B_{j}\right)}{m}\right\}
\end{aligned}
$$

dengan $i=1,2, \ldots, n$ adalah jumlah hipotesa yang diletakkan secara kolom dan $j=1,2, \ldots, m$ adalah jumlah indikasi yang diletakkan secara baris. Total sum of joint probabilities ditunjukkan oleh operasi matematika $\sum_{j=1}^{m} P\left(A_{i} \mid B_{j}\right)$. Faktor pembobotan $m$ adalah jumlah multi indikasi apriori $B$ yang mempengaruhi nilai-nilai probabilitas multi hipotesa $A[7]$.

Tabel 2.2 Ilustrasi Metode MSJP

\begin{tabular}{|l|l|l|l|l|}
\hline$A_{i}$ & \multicolumn{3}{|l|}{ Hipotesa $A i$} \\
\hline$B_{j}$ & & 1 & $\ldots$ & $n$ \\
\hline Indikasi $B j$ & 1 & $P\left(A_{1} \mid B_{1}\right)$ & $\ldots$ & $P\left(A_{n} \mid B_{1}\right)$ \\
\hline & 2 & $P\left(A_{1} \mid B_{2}\right)$ & $\ldots$ & $P\left(A_{n} \mid B_{2}\right)$ \\
\hline & $\ldots$ & $\ldots$ & $\ldots$ & $\ldots$ \\
\hline & $\mathrm{j}$ & $P\left(A_{1} \mid B_{j}\right)$ & $\ldots$ & $P\left(A_{n} \mid B_{j}\right)$ \\
\hline & $\ldots$ & $\ldots$ & $\ldots$ & $\ldots$ \\
\hline & $\mathrm{m}$ & $P\left(A_{1} \mid B_{m}\right)$ & $\ldots$ & $P\left(A_{n} \mid B_{m}\right)$ \\
\hline \multicolumn{5}{|c|}{} \\
\hline
\end{tabular}

\section{Pembahasan}

\subsection{Prediksi Interaksi Gen dalam Deretan Waktu}

Prediksi Interaksi Gen Yeast25 Pada data mengenai nilai interaksi gen-gen yeast 25 tipe elu dalam 18 deretan waktu, baris $G_{i}$ dengan $i=$ $1,2, \ldots, 25$ menunjukkan nama gen-gen yeast yang berjumlah 25 gen, sedangkan kolom $T_{j}$ dengan $j=1,2, \ldots, 18$ menunjukkan waktu ke- $j$. Untuk memprediksi ekspresi interaksi gen tersebut, data ditransformasi terlebih 
dahulu dalam bentuk biner dengan menggunakan threshold berdasarkan nilai rata-rata. Terdapat 2 cara yang dilakukan dalam penentuan nilai threshold, yaitu threshold berdasarkan nilai rata-rata populasi dan thresho$l d$ berdasarkan nilai rata-rata sampel pada tiap baris.

Pada threshold diperoleh nilai rata-rata populasinya adalah:

$$
\mu=\frac{\sum_{i j} x_{i j}}{N}=\frac{2,09}{450}=0,00464
$$

dengan $x_{i j}$ data nilai interaksi gen-gen yeast dengan $i=1,2, \ldots, 25$ dan $j=1,2, \ldots, 18$. Berdasarkan nilai rata-rata yang diperoleh, data akan ditransformasi dalam bentuk biner dengan syarat sebagai berikut:

$$
x_{i j}= \begin{cases}1 & \text { jika } \mathrm{x}_{\mathrm{ij}} \geq \mu \\ 0 & \text { jika } \mathrm{x}_{\mathrm{ij}}<\mu\end{cases}
$$

Data bernilai 1 jika berada di atas nilai rata-rata yang berarti data tersebut memiliki nilai interaksi gen yang kuat. Data bernilai 0 jika berada di bawah rata-rata atau memiliki nilai interaksi gen yang lemah.

Setelah mentransformasi data dalam bentuk biner, ditentukan nilai pembobotan yang diperoleh dari penjumlahan tiap baris, sehingga dapat dikatakan bahwa peluang interaksi gen kuat pada waktu ke- $T_{j}$ dengan syarat gen $G_{i}$ berada pada kelas 1 dinormalisasi dengan nilai bobot pada masingmasing gen. Misalnya pada waktu $T_{1}$ untuk gen FKH1 $G_{3}$ memiliki nilai peluang bersyarat $P\left(T_{1} \mid G_{3}\right)$ sebesar $1 / 10$ atau 0,1 . Nilai 10 merupakan faktor pembobotan pada gen FKH1. Demikian seterusnya untuk mendapatkan peluang bersyarat pada setiap data.

Setelah mendapatkan semua nilai peluang bersyaratnya, ekspresi interaksi gen dari waktu ke waktu dapat diprediksi dengan menggunakan metode MSJP. Contoh perhitungan MSJP berdasarkan persamaan (3) adalah sebagai berikut:

Kolom 1:

$$
\frac{\sum_{j=1} \sum_{i=1}^{25} P\left(T_{1} \mid G_{i}\right)}{N_{i}}=\frac{0,954}{25}=0,038
$$

Kolom 18:

$$
\frac{\sum_{j=18} \sum_{i=1}^{25} P\left(T_{18} \mid G_{i}\right)}{N_{i}}=\frac{2,11}{25}=0,084
$$


Dari perhitungan tersebut diperoleh prediksi ekspresi gen yeast 25 tipe elu untuk interaksi gen selanjutnya memiliki kecenderungan semakin meningkat pada waktu mendatang. Untuk lebih jelasnya, hasil prediksi dapat dilihat pada Gambar 1 berikut ini. Cara kedua adalah mencari threshold ber-

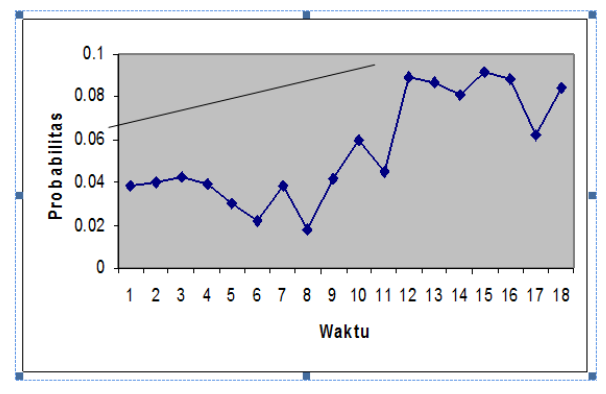

Gambar 1: Interaksi Gen Yeast25-elu dalam 18 Deretan Waktu ke-1

dasarkan nilai rata-rata pada setiap baris. Hal ini digunakan untuk mengetahui hasil yang signifikan dari perhitungan menggunakan metode MSJP, sehingga perlu dilakukan perbandingan antara hasil eksperimen pertama yang menggunakan nilai rata-rata pada seluruh data dengan ekperimen kedua yang dilihat dari rata-rata tiap gen individu dalam 18 deretan waktu.

Threshold untuk nilai rata-rata sampel pada tiap baris diperoleh

$$
\begin{aligned}
& \bar{x}_{1}=\frac{\sum_{j=1}^{18} x_{1, j}}{N_{j}}=0,073 \\
& \vdots \\
& \bar{x}_{25}=\frac{\sum_{j=1}^{18} x_{25, j}}{N_{j}}=0,022
\end{aligned}
$$

Seperti pada eksperimen pertama, transformasi data dalam bentuk biner dilakukan dengan ketentuan sebagai berikut:

$$
\bar{x}_{i}= \begin{cases}1 & , \text { jika } \mathrm{x}_{\mathrm{ij}} \geq \overline{\mathrm{x}}_{\mathrm{i}} \\ 0 & , \text { jika } \mathrm{x}_{\mathrm{ij}}<\overline{\mathrm{x}}_{\mathrm{i}}\end{cases}
$$

dengan $i=1,2, \ldots, 25, j=1,2, \ldots, 18$ dan $\bar{x}_{i}$ merupakan nilai rata-rata pada gen ke- $i$ dalam 18 deretan waktu. 
Dengan cara yang sama, peluang bersyarat $P\left(T_{j} \mid G_{i}=1\right)$ diperoleh dari normalisasi nilai bobotnya. Misalnya pada gen ASH1 $\left(G_{2}\right.$ memiliki nilai bobot 7 , maka peluang bersyarat nilai interaksi kuat pada $T_{3}, P\left(T_{3} \mid G_{2}\right)$ adalah $1 / 7$ atau 0,143 . Setelah itu digunakan metode MSJP untuk memprediksi ekspresi interaksi gen dengan perhitungan sebagai berikut:

Kolom 1:

$$
\frac{\sum_{j=1} \sum_{i=1}^{25} P\left(T_{1} \mid G_{i}\right)}{N_{i}}=\frac{1,02}{25}=0,041
$$

Kolom 18:

$$
\frac{\sum_{j=18} \sum_{i=1}^{25} P\left(T_{18} \mid G_{i}\right)}{N_{i}}=\frac{2,105}{25}=0,084
$$

Dari perhitungan tersebut diperoleh prediksi ekspresi gen yeast25 tipe elu untuk interaksi gen selanjutnya memiliki kecenderungan semakin meningkat pada waktu mendatang. Untuk lebih jelasnya, hasil prediksi dapat dilihat pada Gambar 2.

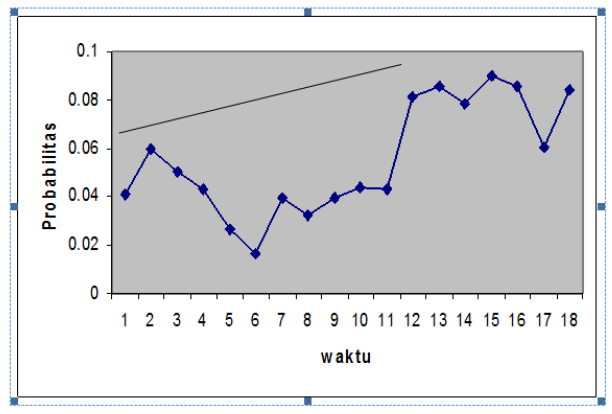

Gambar 2: Interaksi Gen Yeast25-elu dalam 18 Deretan Waktu ke-2

Prediksi Interaksi Gen Yeast36. Pada data mengenai nilai interaksi gen-gen yeast 36 dengan tipe elu dalam 18 deretan waktu, baris $G i$ dengan $i=1,2, \ldots, 36$ menunjukkan nama gen-gen yeast yang berjumlah 36 gen, sedangkan kolom $T j$ dengan $j=1,2, \ldots, 18$ menunjukkan waktu ke- $j$. Sama 
seperti pembahasan sebelumnya bahwa untuk memprediksi ekspresi interaksi gen semakin meningkat atau menurun pada waktu mendatang yaitu dengan mentransformasi data dalam bentuk biner. Pada threshold yang pertama diperoleh nilai rata-rata untuk populasi data gen yeast36 adalah:

$$
\mu=\frac{\sum_{i j} x_{i j}}{N}=\frac{15,09}{648}=0,0233
$$

Dengan cara yang sama, probabilitas bersyarat $P\left(T_{j} \mid G_{i}\right)$ diperoleh berdasarkan pembobotan pada tiap baris. Selanjutnya memprediksi ekspresi interaksi gen dari waktu ke waktu menggunakan metode MSJP. Berdasarkan hasil perhitungan, diperoleh prediksi ekspresi gen yeast36 tipe elu untuk interaksi gen selanjutnya memiliki kecenderungan semakin meningkat. Lebih jelasnya, hasil prediksi dapat dilihat pada Gambar 3.

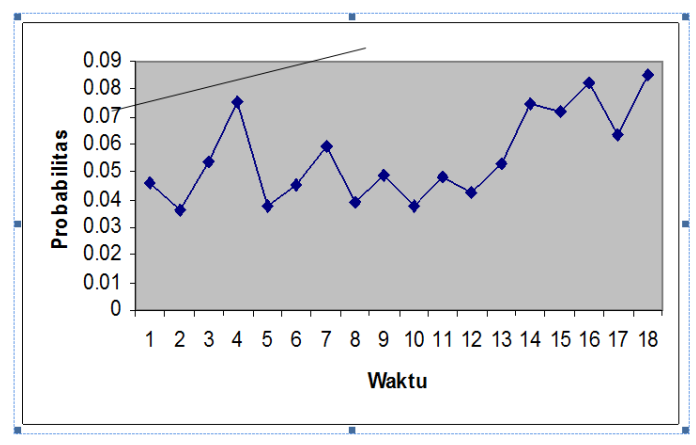

Gambar 3: Interaksi Gen Yeast36-elu dalam 18 Deretan Waktu ke-1

Sedangkan hasil prediksi ekspresi gen yeast36 tipe elu untuk threshold berdasarkan nilai rata-rata sampel juga memiliki kecenderungan semakin meningkat pada waktu mendatang. Untuk lebih jelasnya, hasil prediksi dapat dilihat pada Gambar 4.

\subsection{Prediksi Interaksi Gen Individu dalam Deretan Waktu}

Prediksi Interaksi Gen Individu pada Yeast25 Pada kasus ini, probabilitas setiap gen individu memiliki interaksi gen yang kuat merupakan probabilitas prior yang harus diketahui. Distribusi prior yang digunakan adalah distribusi prior informatif, karena dipilih berdasarkan informasi dari data. Nilai interaksi untuk setiap gen individu dalam 18 deretan waktu 


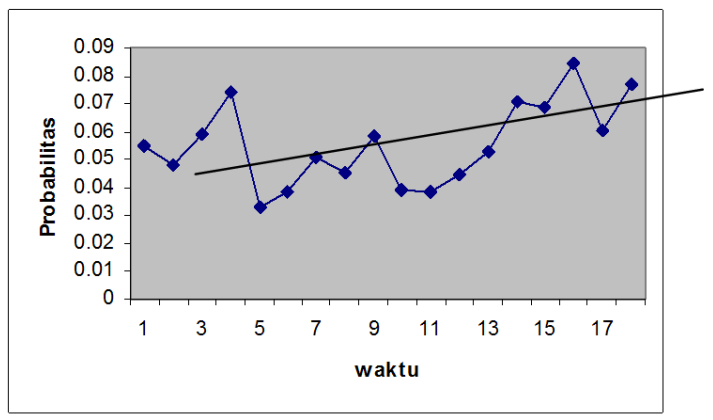

Gambar 4: Interaksi Gen Yeast36-elu dalam 18 Deretan Waktu ke-2

diasumsikan berdistribusi normal. Masing-masing gen individu memiliki nilai probabilitas prior yang berbeda. Namun pada tiap gen mempunyai peluang yang sama untuk memiliki nilai interaksi gen yang kuat dari waktu ke waktu, sehingga principle of indifference diberlakukan.

Langkah-langkah untuk mendapatkan probabilitas prior pada masingmasing gen yeast 25 individu dijelaskan sebagai berikut:

1. Nilai rata-rata sebelumnya untuk populasi yeast 25 yaitu $\mu=0,00464$ dijadikan sebagai dasar untuk mencari probabilitas prior setiap gen, $P(X \geq 0,00464)$.

2. Menghitung probabilitas prior $P\left(Z \geq z_{i}\right)$ yang sepadan dengan $P(X \geq 0,00464)$, dengan $x$ merupakan nilai rata-rata populasi, $\bar{x}_{i}$ merupakan nilai rata-rata sampel pada gen ke- $i$ dalam 18 deretan waktu dan standar deviasi $s_{i}$.

Misalnya, pada gen ACE2 $\left(G_{1}\right)$ dalam 18 deretan waktu mengikuti sebaran normal dengan mean 0,07333 dan standar deviasi 0,7406. Probabilitas prior gen ACE2 yang memiliki interaksi gen kuat terletak pada daerah $P(X \geq 0,00464)$. Nilai $z_{i}$ padanan $x=0,00464$ adalah

$$
z_{1}=\frac{x-\mu_{1}}{\sigma_{1}}=\frac{0,00464-0,07333}{0,7406}=-0,0927
$$


Dengan demikian, probabilitas prior pada gen ACE2 adalah

$$
\begin{aligned}
P(X \geq 0,00464) & =P(Z \geq-0,0927) \\
= & 1-P(Z<-0,0927) \\
= & 1-0,4641 \\
= & 0,5359
\end{aligned}
$$

Perhitungan yang sama juga diaplikasikan pada tiap gen untuk mendapatkan probabilitas prior.

Probabilitas posterior dapat ditentukan setelah mendapatkan probabilitas prior pada setiap gen. Probabilitas posterior yang dimaksud adalah peluang $G_{i}$ yang memiliki interaksi gen yang kuat pada waktu $T_{j}$, dinyatakan dengan $P\left(G_{i} \mid T_{j}\right)$. Probabilitas posterior pada kasus ini adalah

$$
\begin{aligned}
P\left(G_{i} \mid T_{j}\right) & =\frac{P\left(T_{j} \mid G_{i}\right) P\left(G_{i}\right)}{P\left(T_{j}\right)} \\
& =\frac{P\left(T_{j} \mid G_{i}\right) P\left(G_{i}\right)}{\sum_{i=1}^{25} P\left(T_{j} \mid G_{i}\right) P\left(G_{i}\right)}
\end{aligned}
$$

dengan $P(T j \mid G i)$ merupakan probabilitas ekspresi gen kuat pada waktu $T_{j}$ dengan syarat gen $G_{i}$ berada pada kelas 1 atau memiliki nilai interaksi gen yang kuat, sedangkan $P(G i)$ merupakan probabilitas prior untuk setiap gen $G_{i}$.

Misalnya, pada gen FKH1 $G_{3}$ memiliki probabilitas prior $P(G 3) 0,5398$. Probabilitas posterior $G_{3}$ memiliki interaksi gen yang kuat pada waktu $T_{2}$ adalah

$$
\begin{aligned}
P\left(G_{3} \mid T_{2}\right) & =\frac{P\left(T_{2} \mid G_{3}\right) P\left(G_{3}\right)}{P\left(T_{2}\right)} \\
& =\frac{P\left(T_{2} \mid G_{3}\right) P\left(G_{3}\right)}{\sum_{i=1}^{25} P\left(T_{2} \mid G_{i}\right) P\left(G_{i}\right)}=0,101
\end{aligned}
$$

Setelah mendapatkan probabilitas posterior, dapat diprediksi gen yang memiliki ekspresi tertinggi dengan menggunakan metode MSJP. Berikut ini perhitungan MSJP untuk masing-masing gen dengan menggunakan persamaan

$$
\begin{gathered}
P\left(G_{1} \mid T_{1}, T_{2}, \ldots, T_{18}\right)=\frac{\sum_{j=1}^{18} P\left(G_{1} \mid T_{j}\right)}{j}=\frac{0,666}{18}=0,037 \\
\vdots \\
P\left(G_{25} \mid T_{1}, T_{2}, \ldots, T_{18}\right)=\frac{\sum_{j=1}^{18} P\left(G_{25} \mid T_{j}\right)}{j}=\frac{0,72}{18}=0,04
\end{gathered}
$$


Pada perhitungan tersebut diperoleh gen yang memiliki peluang tertinggi menghasilkan ekspresi terbesar untuk interaksi gen yeast 25 tipe elu dalam 18 deretan waktu adalah gen FAR1 dengan peluang 0,058. Probabilitas tiap gen individu dapat dilihat pada Gambar 5.

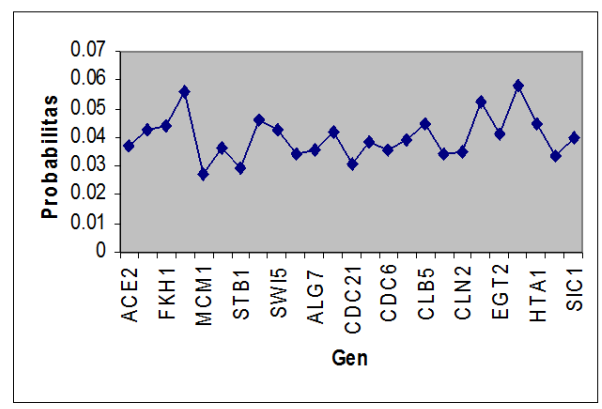

Gambar 5: Probabilitas Gen Individu pada Yeast25- elu dalam 18 deretan waktu

Prediksi Interaksi Gen Individu pada Yeast36 Seperti pembahasan sebelumnya, prediksi interaksi gen individu pada gen yeast 36 juga dianalisis menggunakan metode Bayesian. Oleh karena itu, probabilitas prior pada tiap gen individu $P\left(G_{i}\right)$ dibutuhkan untuk mendapatkan probabilitas posterior $P\left(G_{i} \mid T_{j}\right)$.

Berikut ini perhitungan yeast36 tipe elu dalam 18 deretan waktu dapat diperoleh dengan menggunakan metode MSJP pada setiap gen, yaitu:

$$
\begin{aligned}
& P\left(G_{1} \mid T_{1}, T_{2}, \ldots, T_{18}\right)=\frac{\sum_{j=1}^{18} P\left(G_{1} \mid T_{j}\right)}{j}=\frac{0,534}{18}=0,03 \\
& \quad \vdots \\
& P\left(G_{36} \mid T_{1}, T_{2}, \ldots, T_{18}\right)=\frac{\sum_{j=1}^{18} P\left(G_{36} \mid T_{j}\right)}{j}=\frac{0,461}{18}=0,026
\end{aligned}
$$

Pada perhitungan tersebut diperoleh gen yang memiliki peluang tertinggi menghasilkan ekspresi terbesar pada interaksi gen yeast36 tipe elu adalah gen MET16 dengan peluang 0,036. Probabilitas tiap gen individu dapat dilihat pada Gambar 6. Dari hasil penelitian mengenai ekspresi interaksi 


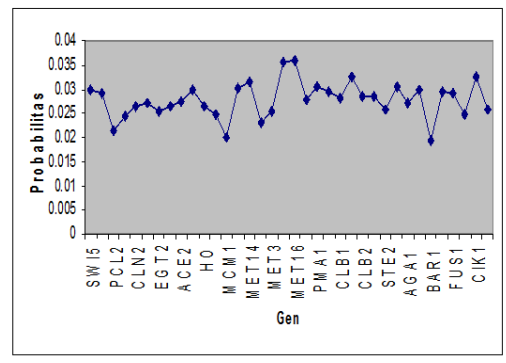

Gambar 6: Probabilitas Gen Individu pada Yeast36- elu dalam 18 deretan waktu

gen yeast, dapat diketahui bahwa gen FAR1 merupakan gen yang paling berkontribusi pada interaksi gen yeast 25 tipe elu dan gen MET16 merupakan gen yang paling berkontribusi pada interaksi gen yeast36 tipe elu. Gen-gen yang telah diperoleh dapat mempermudah peneliti untuk memeriksa ekspresi gen tersebut, sebab pemeriksaan interaksi gen menjadi lebih fokus. Jika ekspresi gen-gen tersebut menghasilkan mutasi yang positif untuk offspring (keturunan), maka fungsi dari gen-gen tersebut dapat dipertahankan. Namun, jika menghasilkan mutasi negatif untuk offspring, maka dapat dilakukan mutasi balik untuk mengurangi ekspresi gen-gen tersebut sehingga menciptakan offspring yang lebih baik di masa yang akan datang.

\section{Kesimpulan dan Saran}

Dari hasil pembahasan mengenai prediksi ekspresi interaksi gen dengan menggunakan metode Maximum Score of the Total Sum of Joint Probabilities (MSJP) dapat disimpulkan sebagai berikut:

1. Hasil dari prediksi interaksi gen yeast 25 dan yeast36 tipe elu dalam 18 deretan waktu dengan menggunakan pendekatan 2 threshold yang berbeda, konsep probabilitas dan metode MSJP menyatakan bahwa ekspresi interaksi gen tersebut memiliki kecenderungan semakin meningkat di waktu mendatang. 
2. Dengan menggunakan analisis Bayesian dan metode MSJP dalam pengambilan keputusan diperoleh gen yang paling berkontribusi memiliki ekspresi tertinggi pada interaksi gen yeast 25 tipe elu dalam 18 deretan waktu adalah FAR1 dengan nilai probabilitas sebesar 0,058. Sedangkan gen yang paling berkontribusi memiliki ekspresi tertinggi pada interaksi gen yeast 36 tipe elu dalam 18 deretan waktu adalah MET16 dengan nilai probabilitas sebesar 0,036.

Adapun saran dari peneliti adalah perlu adanya pemilihan prior lebih dari satu dengan metode berbeda yang dianggap representatif pada analisis data menggunakan metode Bayesian. Hasil analisis Bayesian dengan prior yang berbeda dijadikan sebagai perbandingan sehingga penggunaan metode MSJP benar-benar menghasilkan suatu keputusan yang tepat.

\section{Pustaka}

[1] Ahmad, A. S., Sumari, A.D.W, dan Zubir, H. Y. Collaborative Computation in Bioinformatics for Better Life, Prosiding Seminar Nasional Teknologi Informasi dan Aplikasinya (SENTIA, Politeknik Negeri Malang, Malang, 2009.

[2] Dudewicz, E. J. dan Mishra, S. N, Statistika Matematika Modern, Diterjemahkan oleh RK Sembiring, Bandung, ITB, 1995.

[3] Gelman, Andrew, Bayesian Data Analysis, 1st ed, Chapman \& Hall, Britain, 1995.

[4] Sarwoko, Statistik Inferensi untuk Ekonomi dan Bisnis, Andi, Yogyakarta, 2007.

[5] Siegel, A. F. dan Morgan, C.J., Statistics and Data Analysis An Introduction, 2nd edition, John Wiley \& Son, Inc., 1996.

[6] Sumari, A.D.W. dan Ahmad, A.S., Design and Implementation of Multi Agentbased Information Fusion System for Decision Making Support (A Case Study on Military Operation), ITB J. ICT. Vol. 2, No. 1, 42-63, 2008. 
[7] Sumari, A.D.W., dkk, Pengembangan Teori Probabilitas untuk Fusi Penginferensian Informasi, Prosiding Seminar Nasional Matematika IV. ITS, Surabaya, 2008.

[8] Walpole, R.E., Pengantar Statistika, Edisi ke-3 , Gramedia Pustaka Utama, Jakarta, 1992. 